\title{
Age and growth of black scabbardfish (Aphanopus carbo Lowe, 1839) in the southern NE Atlantic
}

\author{
ANA RITA VIEIRA ${ }^{1}$, INÊS FARIAS ${ }^{2}$, IVONE FIGUEIREDO ${ }^{2}$, ANA NEVES ${ }^{1}$, \\ BEATRIZ MORALES-NIN ${ }^{3}$, VERA SEQUEIRA ${ }^{1}$, MARIA ROGÉLIA MARTINS ${ }^{2}$ \\ and LEONEL SERRANO GORDO ${ }^{1}$
}

\author{
${ }^{1}$ Departamento de Biologia Animal and Centro de Oceanografia, Faculdade de Ciências da Universidade de Lisboa, Bloco \\ C2, Campo Grande, 1749-016 Lisboa, Portugal. E-mail: ana.vieira83@ gmail.com \\ ${ }^{2}$ Unidade de Recursos Marinhos e Sustentabilidade, IPIMAR, Av. Brasília, 1449-006 Lisboa, Portugal. \\ ${ }^{3}$ CSIC/UIB, Institut Mediterrani d'Estudis Avançats, Miguel Marqués 21, 07190 Esporles, Spain.
}

\begin{abstract}
SUMMARY: Though whole otoliths are commonly adopted in age assignment of black scabbardfish, this study showed that sectioned otoliths are more appropriate because growth increments are more evident and ageing of larger specimens is easier. Vertebrae are not the most appropriate structure for ageing but, in the absence of otoliths, this structure may be useful in age assignment of this species. To verify possible differences between age and growth among specimens from the southern NE Atlantic, 1075 sectioned otoliths from specimens from mainland Portugal, 436 from Madeira and 107 from the Azores were analysed and the distribution of length-at-age obtained for each sex and region was determined. Significant differences were obtained in the comparison of the distribution of length-at-age between Madeira, the mainland and the Azores. The von Bertalanffy growth model was applied to back-calculated mean length-at-age data from Madeira $\left(L_{t}=1586\left[1-e^{-0.119(t+2.282)}\right]\right.$ females; $L_{t}=1461\left[1-e^{-0.146(t+1.441)}\right]$ males $)$ and mainland $\left(L_{t}=1354\left[1-e^{-0.170(t+2.040)}\right]\right.$ females; $L_{t}=1240\left[1-e^{-0.208(t+1.654)}\right]$ males), and significant differences in the growth equations were obtained. Furthermore, a regression tree model was used to investigate how growth is conditioned by reproduction. The results showed a clear separation between individuals from the two areas, both females and males from the mainland (non-reproductive individuals) being characterised by a lower gonadosomatic index and a lower age.
\end{abstract}

Keywords: Aphanopus carbo, black scabbardfish, whole and sectioned otoliths, vertebrae, precision estimators, age and growth.

RESUMEN: EDAD y CRECIMIENTO EN EL SABLE NEGRo (APHANOPUS CARBo LOWE, 1839) DEL SUR DE ATLÁNTICO NORDESTE. - A pesar de que los otolitos enteros son adoptados normalmente en lecturas de edad del sable negro, este estudio mostró que los otolitos seccionados son más apropiados porque los incrementos de crecimiento son más evidentes y facilita la asignación de edad en los peces de mayor talla. Las vértebras no son las estructuras más apropiadas para asignar la edad del sable negro, pero en ausencia de otolitos, esta estructura puede resultar de utilidad en dicho proceso. Para verificar posibles diferencias entre la edad y el crecimiento de especimenes viviendo en el sur del Atlántico nordeste, 1075 otolitos seccionados de ejemplares de sable negro de Portugal continental, 436 de Madeira y 107 de Azores fueron analizados, y se obtuvieron las distribuciones de tallas por edad por sexo, en cada región. Fueron observadas diferencias significativas en la comparación de las distribuciones de talla por edad entre Madeira, continente y Azores. El modelo de crecimiento de von Bertalanffy fue aplicado a los datos retrocalculados de talla media por grupo de edad de Madeira $\left(L_{t}=1586\left[1-e^{-0.119(t+2.282)}\right]\right.$ hembras; $L_{t}=$ $1461\left[1-e^{-0.146(t+1.441)}\right]$ machos) y continente $\left(L_{t}=1354\left[1-e^{-0.170(t+2.040)}\right]\right.$ hembras; $L_{t}=1240\left[1-e^{-0.208(t+1.654)}\right]$ machos $), y$ fueran encontradas diferencias significativas en las ecuaciones de crecimiento. Además, un modelo de árbol de regresión fue utilizado para estudiar cómo el crecimiento es condicionado por la reproducción. Los resultados mostraron una separación clara entre individuos de las dos áreas, caracterizándose tanto las hembras como los machos del continente (individuos no reproductivos) por un índice gonadosomatico y una edad más baja.

Palabras clave: Aphanopus carbo, sable negro, otolitos enteros y seccionados, vértebras, estimadores de precisión, edad y crecimiento. 


\section{INTRODUCTION}

Age determination provides essential input data for the assessment of marine fish stocks (Hilborn and Walters, 1992). Using the periodicity in the formation of growth increments of calcified hard structures, such as scales, otoliths, fin rays and vertebrae, the age of fish can usually be estimated (Campana, 2001). Otoliths have been largely used in age and growth studies, since it is assumed that they contain information on the entire growth history of the individual fish (Bergstad, 1995). The mechanism regulating cyclic deposition of growth increments in the form of opaque and translucent increments in otoliths is not well understood (Beckman and Wilson, 1995) but it is commonly assumed to be related to seasonal variation in somatic growth and environmental factors (Campana, 1999). In deep water fish this formation is linked to spawning and seasonal variation in food availability (Morales-Nin and Panfili, 2005).

The black scabbardfish (Aphanopus carbo Lowe, 1839 ) is a benthopelagic species that occurs at depths ranging from 200 to $2300 \mathrm{~m}$ (Pajuelo et al., 2008), and is caught in Portuguese waters mainly at depths ranging from 800 to $1200 \mathrm{~m}$ (Martins et al., 1987). The species' life cycle is not fully understood. Until very recently the only documented area of reproduction was around Madeira Island, where spawning takes place mainly between October and December (Carvalho, 1988) and 50\% of the population is mature at a length of $103 \mathrm{~cm}$ (Figueiredo et al., 2003). To the west of the British Isles and off the Portuguese coast, most of the captured specimens have lengths greater than $80 \mathrm{~cm}$ and are immature or at an early stage of development (Kelly et al., 1998; Anon., 2000). Juveniles (here considered as specimens with total length smaller than $60 \mathrm{~cm}$ ) are not commonly caught.

The stock structure of black scabbardfish is still unknown in the northeast Atlantic (Large et al., 2003). Swan et al. (2003), based on otolith microchemistry, have suggested that there is a single stock. On the other hand, Quinta et al. (2004), based on the frequency of the mtDNA restriction patterns, raised the hypothesis of the existence of two separate stocks: one near the Madeira archipelago and the other including individuals from mainland Portugal and Hatton Bank. More recently, Stefanni and Knutsen (2007), using the same molecular technique (mtDNA), stated the hypothesis that the specimens living off Madeira and mainland Portugal and at the
mid-Atlantic Ridge (Faraday seamount) may belong to the same stock unit.

Growth studies based on black scabbardfish whole otoliths and sectioned otoliths showed different results. In the former, black scabbardfish was considered to have a relatively fast growth rate with a maximum age of 8 years (Morales-Nin and SenaCarvalho, 1996), whereas in the latter the growth rate was considered to be much slower, with a maximum observed age of 32 years (Kelly et al., 1998). Most recently, Morales-Nin et al. (2002) determined the maximum age to be 12 years, considering that whole otoliths were the most appropriate structure for age readings. Pajuelo et al. (2008), in a study with whole burned otoliths, reported that black scabbardfish of the Canary Islands has a relatively short life span, attaining ages of up to 12 years.

Other structures apart from otoliths have not been tested for ageing this species. However, when specimens are landed without the head (as in the case of the French black scabbardfish fishery) the use of other calcified structures (e.g. vertebrae) may be helpful to provide information on the population age structure.

This paper therefore has three sequential main goals:

- To evaluate the most appropriate methodology for ageing taking into account bias and precision of readers and reading methodology.

- To compare the age and growth of the species caught in waters of mainland Portugal, Madeira and the Azores.

- To investigate how growth is conditioned by reproduction.

\section{MATERIAL AND METHODS}

\section{Sampling}

The presence of a second species of the genus Aphanopus (A. intermedius) was detected in the southern northeast Atlantic in the early 1990s (Nakamura and Parin, 1993), more recently off the Azores (Stephanni and Knutsen, 2007) and Madeira, but never in mainland waters (Sara Reis, pers. comm.). The two species are morphologically similar: A. intermedius has 102108 vertebrae and 40-44 dorsal fin spines, whereas $A$. carbo has 97-100 vertebrae and 38-40 dorsal fin spines (Nakamura and Parin, 1993). To ensure that only A. carbo was sampled, an effort was made to determine 

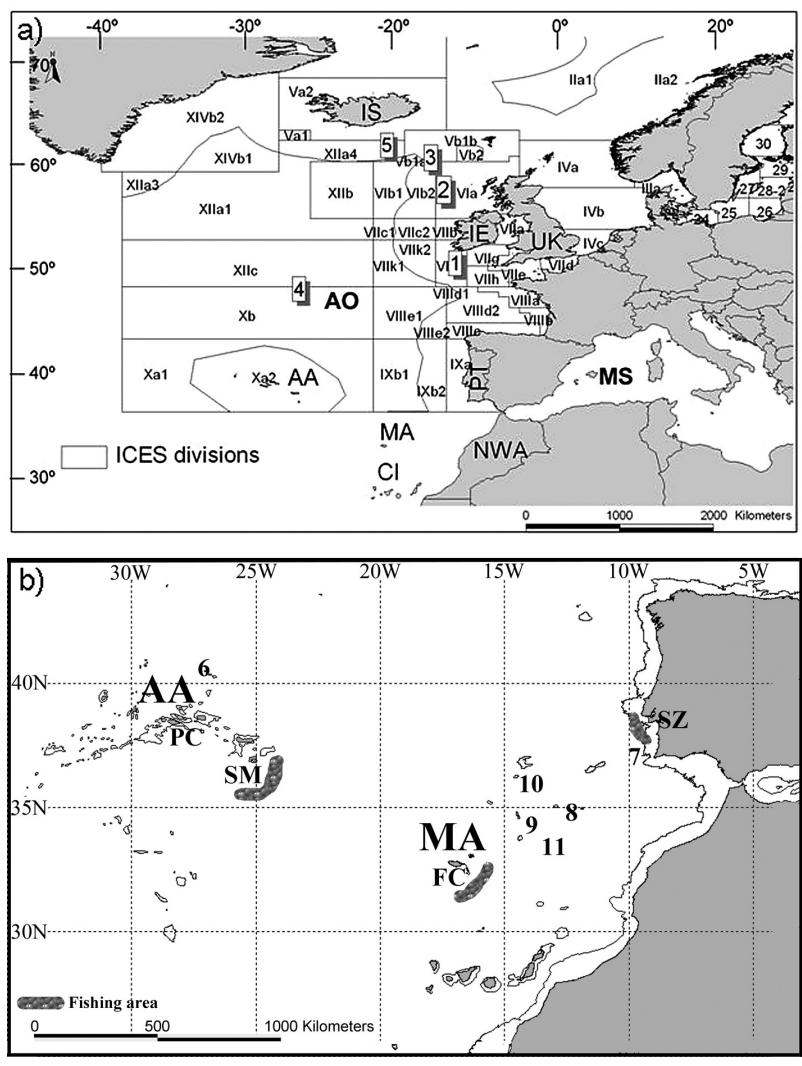

FIG. 1. - a) Map of the northeast Atlantic with the ICES divisions and b) the southern northeast Atlantic with the sampling locations of black scabbardfish and the $1000 \mathrm{~m}$ isobath. AA, Azores Archipelago; AO, Atlantic Ocean; CI, Canary Islands; FC, Funchal; IE, Ireland; IS, Iceland, MA, Madeira Archipelago; MS, Mediterranean Sea; NWA, Northwest Africa; PC, Pico Island; PT, mainland Portugal; SM, Santa Maria Island; SZ, Sesimbra (mainland Portugal); UK, United Kingdom; 1, Porcupine Seabight; 2, Rockall Trough; 3, Hatton Bank; 4, Faraday seamount; 5, Reykjanes Ridge; 6, Sedlo seamount; 7, Gorringe seamount; 8 , Ampère seamount; 9 , Unicorn bank; 10, Lion seamount; 11, Seine seamount.

whether specimens from A. intermedius were present in the samples and every individual morphologically analysed belonged to $A$. carbo.

Between May 2005 and December 2007, the majority of the otoliths and vertebrae used in this study were collected from fishes caught off Sesimbra (mainland Portugal) and Funchal (Madeira archipelago) from commercial vessels using longline, but other otoliths were also obtained from fishes caught in an exploratory fishery conducted by some Madeira vessels operating in the Azores (Fig. 1). In the laboratory, all individuals were measured to the nearest millimetre total length (TL) and weighed to the nearest gram of total weight (TW). In each specimen, the gonads were weighed to the nearest centigram (GW), the sex was determined and the maturity stage was assigned using the maturity scale defined by Gordo et al. (2000). The gonadosomatic index (GSI), which expresses gonad weight divided by total weight, was also estimated for each individual fish. Otoliths were extracted, cleaned, dried and kept in envelopes. Vertebrae were extracted from the body portion between the $20^{\text {th }}$ and $25^{\text {th }}$ anal fin rays counting from the posterior end of the fish.

\section{Ageing methodology}

\section{Sample preparation}

Table 1 summarises the number of otoliths used for this methodology and their source. For ageing, whole left otoliths from each pair were immersed in a 1:1 glycerin-alcohol solution, with sulcus acusticus placed downwards under a stereomicroscope with a micrometric ocular and a magnification of $18 \times$ using reflected light and a dark background. Right otoliths were prepared for age reading using the thin-sections technique (Bedford, 1983; McCurdy, 1985). They were transversally sectioned with a diamond-tipped saw blade (Labcut 230 Cutting Machine) rotating at $3700 \mathrm{rpm}$. Slides $0.5 \mathrm{~mm}$ thick were mounted in a glass slide with translucent glue, brushed with a 1:1 glycerin-alcohol solution and observed in a stereomicroscope with a micrometric ocular under transmitted light and an $18 \times$ magnification.

Vertebrae were immersed in a solution of $5 \%$ tripsin in phosphate buffer for 1 hour at $50^{\circ} \mathrm{C}$ (to remove the muscle) and washed with distilled water; the remaining tissue was brushed out. For growth increment observation, vertebrae were immersed in a 1:1 glycerin-alcohol solution fixed with black plastic dough in a position that allowed a complete view of the whole surface, and observed under a binocular stereoscope with reflected light and a magnification

TABLE 1. - Origin, number and length range of specimens of Aphanopus carbo used for the comparison of ageing structures (whole and sectioned otoliths and vertebrae).

\begin{tabular}{|c|c|c|c|c|c|c|}
\hline \multirow[t]{2}{*}{ Area } & \multirow[t]{2}{*}{ No. fish } & \multicolumn{2}{|c|}{ Total length (mm) } & \multirow[b]{2}{*}{ Whole otoliths } & \multirow{2}{*}{$\begin{array}{l}\text { Structures comparison } \\
\text { Sectioned otoliths }\end{array}$} & \multirow[b]{2}{*}{ Vertebra } \\
\hline & & Min & $\operatorname{Max}$ & & & \\
\hline Madeira & 120 & 1250 & 1481 & yes & yes & no \\
\hline Mainland & 144 & 641 & 1314 & yes & yes & yes \\
\hline
\end{tabular}


of $15 \times$. Vertebrae were photographed with a digital camera connected to a computer and the digital image was processed using the TNPC 4.1 software integrated in Visilog 6.3.0.

The main assumptions for age assignment were: (i) an annual growth increment corresponds to the succession of an opaque and a translucent band (corroborated for Madeira samples by Morales-Nin et al. (2002) but needs to be validated by marginal increment analysis (MIA) for mainland samples), so age can be assigned by counting only translucent bands; (ii) 1 January is considered to be the birth date since the spawning season occurs in the last quarter of the year (Figueiredo et al., 2003; Neves et al., 2009).

To select the most appropriate procedure for ageing black scabbardfish specimens, readings were made on the ventral and dorsal faces of whole and sectioned otoliths, and on the rostrum and posterior region of whole otoliths. For all readings, including in vertebrae, the distance of each increment relative to the nucleus was measured.

\section{Precision and bias}

To compare the precision between methods and between readers, whole and sectioned otoliths and vertebrae were aged by two readers (Reader 1 and Reader 2). To compare age readings we used the average percentage error (APE) (Beamish and Fournier, 1981), which can be calculated for a respective series of determinations (either by the same reader or by different readers) and is dependent on the average age of the fish species investigated:

$$
\operatorname{APE}_{j}(\%)=100 \times \frac{1}{R} \sum_{i=1}^{R} \frac{\left|X_{i j}-X_{j}\right|}{X_{j}}
$$

where $R$ is the number of times each fish is aged, $X_{i j}$ the $i\left(\right.$ th) age determination of the $j\left(\right.$ th) fish, and $X_{j}$ is the mean age calculated for the $\mathrm{j}($ th) fish.

Chang (1982) modified this index to a coefficient of variation $(\mathrm{CV})$, substituting the absolute deviation by the standard deviation from the mean age:

$$
\mathrm{CV}_{\mathrm{j}}(\%)=100 \times \frac{\sqrt{\sum_{\mathrm{i}=1}^{\mathrm{R}} \frac{\left(\mathrm{X}_{\mathrm{ij}}-\mathrm{X}_{\mathrm{j}}\right)^{2}}{\mathrm{R}-1}}}{\mathrm{X}_{\mathrm{j}}} .
$$

APE and CV produce similar values (Chang, 1982), but the latter is statistically more rigorous and thus is more flexible (Campana et al., 1995).
The same applies to the index of precision D (Chang, 1982), which is similar to CV and is calculated as:

$$
\mathrm{D}_{\mathrm{j}}=\frac{\mathrm{CV}_{\mathrm{j}}}{\sqrt{\mathrm{R}}} .
$$

The parametric paired t-test was used to compare assigned ages between methods and between readers.

A test for symmetry through the Bowker-type test (Bowker, 1948) was used to detect systematic differences between the ages assigned by the two readers (Hoenig et al., 1995). Bowker's method was designed to test the hypothesis that an $m \times m$ contingency table consisting of two classifications of ages assigned by two readers is symmetric about the main diagonal (Bowker, 1948).

\section{Age determination and growth comparisons}

A total of 1618 fish (936 collected during the project between May 2005 and December 2007 and 682 from an extra sample between July 1998 and April 2005) were sampled in the study areas (Table 2 ). The annual periodicity of the growth increments was indirectly validated by the evolution of the marginal increment in the otoliths during the year. Once the annual nature of the growth increments had been validated, the age was determined as the number of translucent growth increments and age-length keys were obtained for sex, year and region.

Since population age composition can vary temporally within stocks (Begg et al., 1999), a comparison of the distributions of length-at-age was done for samples from mainland Portugal (considering four time series: 1998-1999, 2000-2001, 2004-2005 and 2006-2007) and Madeira (assuming two time

TABLE 2. - Number of otoliths of Aphanopus carbo used in each year and study area.

\begin{tabular}{lccc}
\hline Year & Azores & Madeira & Mainland \\
\hline Extra sample & & & \\
1998 & & & 87 \\
1999 & & 37 & 68 \\
2000 & 46 & 81 \\
2001 & & & 142 \\
2004 & & 197 & 127 \\
Project & 50 & 156 & 213 \\
2005 & 57 & & 247 \\
2006 & 107 & 436 & 110 \\
Total & 107 & & 1075 \\
\hline
\end{tabular}


series: 2000-2001 and 2005-2006). The absence of differences between the time series would result in a unique age-length key for sex and region. Therefore, to determine whether there were differences between areas, the non-parametric Mann-Whitney test was applied to the length distributions at the same ages that showed a minimum of 10 individuals per age group (Erzini, 1994).

The distributions of length-at-age were then compared for the same age range to test each of the three hypotheses: (i) there are no differences in the distributions of length-at-age between males and females; (ii) there are no differences in the distributions of length-at-age between the two geographic areas that showed a higher number of individuals (Madeira and mainland Portugal) and for each sex; and (iii) there are no differences in the distributions of length-atage between the three areas in comparison.

To estimate fish growth, due to the absence of low ages back calculation methodology was applied to sectioned otoliths from mainland Portugal and Madeira (Azores samples were not included because there were insufficient data to perform this analysis, resulting in unreliable growth parameters estimates). A total of 874 otoliths were measured using a micrometer eyepiece and the distances between the nucleus and the edge and between the nucleus and the successive growth increments were recorded. The relationships between the total length (TL) and the otolith radius (OR) were established by power regression. The von Bertalanffy growth model (von Bertalanffy, 1938) was applied to back calculation mean length-at-age using FiSAT computer software (Gayanilo et al., 2005) and the growth parameters were compared using Hotelling's $\mathrm{T}^{2}$ test (Bernard, 1981).

\section{Reproduction effect upon growth}

A regression tree model was used to investigate how growth was conditioned by reproduction (GSI and maturity). The gonadosomatic index values were treated as the response variable and age and maturity stage were treated as explanatory variables. The regression tree was adjusted for each sex in two distinct groups of specimens: specimens from Madeira, where the whole reproductive cycle is known to occur (Figueiredo et al., 2003) and specimens from mainland Portugal, where the maturity cycle is recognised to be interrupted at an early development maturity stage (Neves et al., 2009).

\section{RESULTS}

\section{Ageing methodology}

Black scabbardfish whole otoliths are oblong and show translucent and opaque growth increments around a central opaque elongate area-the otolith nucleus. In whole and sectioned otoliths, the first growth increment corresponded to the first well marked band after the appearance of two or three faint rings, as reported by Morales-Nin et al. (2002). Despite the variability in the deposition of the first growth increment between different whole otoliths, the first increment appeared at the following distances from the nucleus (mean \pm S.D.): $2.16 \pm 0.04 \mathrm{~mm}$ at the rostrum, $1.65 \pm 0.05 \mathrm{~mm}$ in the posterior region, $0.75 \pm 0.02 \mathrm{~mm}$ on the dorsal face and $0.58 \pm 0.03 \mathrm{~mm}$ on the ventral face. In sectioned otoliths, the first increment appeared at the following distances from the nucleus: $0.73 \pm 0.01 \mathrm{~mm}$ on the dorsal face and $0.56 \pm 0.02 \mathrm{~mm}$ on the ventral face.

In vertebrae the first growth increment was considered to be the one with a high frequency of occurrence that was well marked in all vertebrae. This increment appeared at $1.29 \pm 0.06 \mathrm{~mm}$ of the total vertebra radius.

After the establishment of the first increment, the subsequent ones were considered to be those with a marked band. For smaller specimens (TL $<1100$ $\mathrm{mm}$ ), there was a consistency in the number of growth increments counted in whole and sectioned
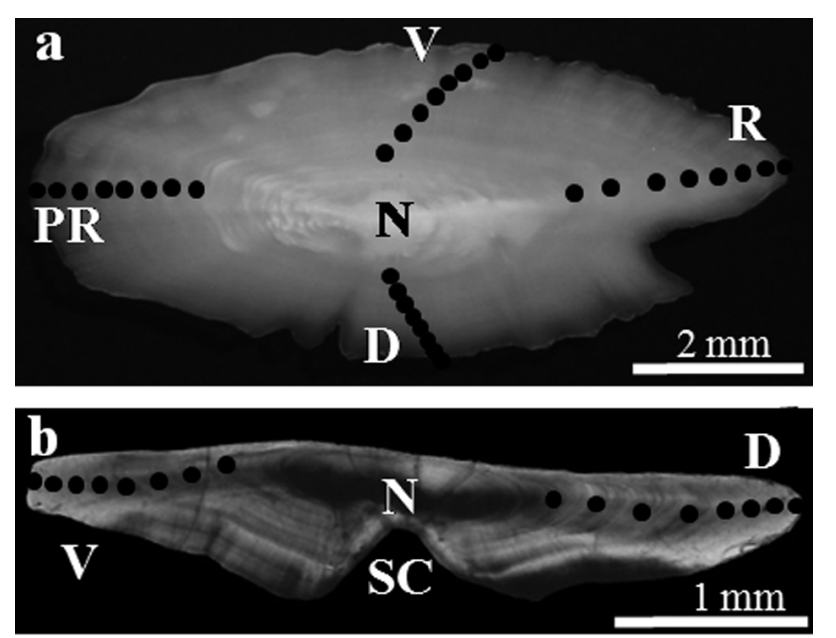

FIG. 2. - Number of growth increments observed between different areas of the same otolith and between whole and sectioned otoliths from Aphanopus carbo caught off mainland Portugal. Black dots represent growth increments. (a) Left whole otolith (specimen with $1083 \mathrm{~mm}$ total length and 8 years). (b) Equivalent right sectioned otolith. PR: posterior region; V: ventral face; R: rostrum; D: dorsal face; SC: sulcus acusticus; N: nucleus. 

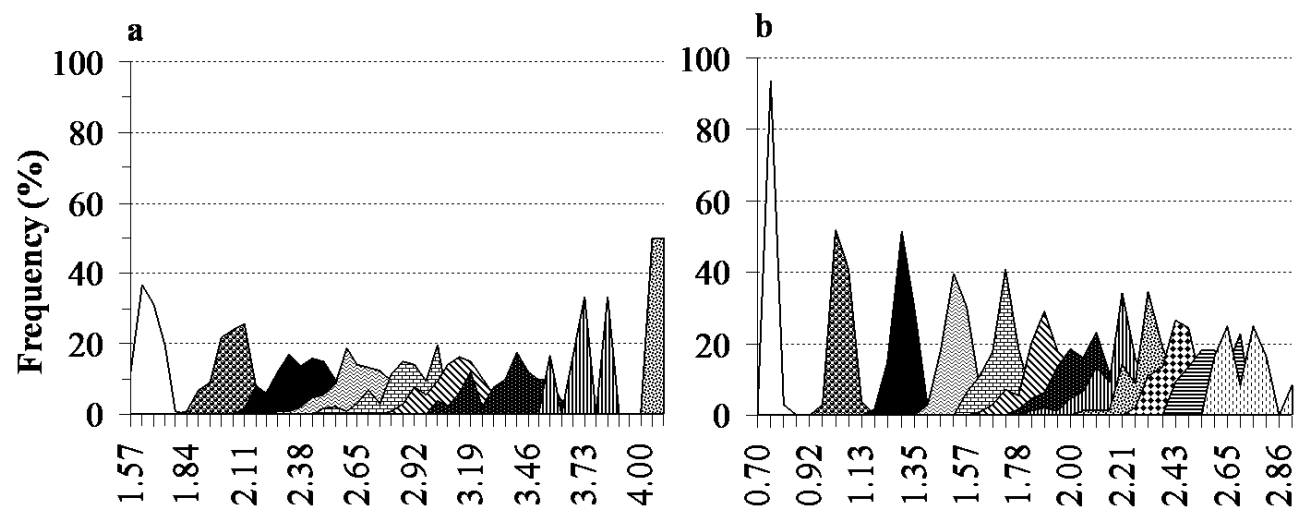

$\square$ Age 1

준 Age 2

Age 3

图 Age 4

園 Age 5

Age 6

四 Age 7

血 Age 8

图 Age 9

Age 10

目 Age 11

Distance from nucleus to growth increment (mm)

國 Age 12

FIG. 3. - Individualisation of growth increments by age from Aphanopus carbo otoliths caught off mainland Portugal. (a) Age assignment procedure in posterior region of whole otoliths. (b) Age assignment procedure in dorsal face of sectioned otoliths.

otoliths, and in different reading areas of each otolith (rostrum, posterior region, dorsal and ventral faces of whole otoliths; dorsal and ventral faces of sectioned otoliths) (Fig. 2a and b).

The analysis of whole otoliths of the larger specimens (TL>1100 mm) involves some difficulty, in particular, in the observation of growth increments, when compared with the whole otoliths of smaller fishes (TL $<1100 \mathrm{~mm}$ ). On the other hand, in the sectioned otoliths, the growth increments can be more easily seen (particularly on the dorsal face) in both small and large specimens (Fig. 2b).

The posterior region of whole otoliths (Fig. 2a) and the dorsal face of sectioned otoliths (Fig. 2b) seemed to provide a better individualisation of the growth increments due to the greater sharpness and the larger distance between them, respectively, and should be chosen in future age reading studies. In the sample of whole otoliths from the mainland, the increment corresponding to 1 year was completely individualised from the increment corresponding to age 2, although the other increments showed some overlap, increasing with fish age (Fig. 3a). On the dorsal face of sectioned otoliths, the increments corresponding to 1,2 and 3 years were completely individualised, marking between 0.70 and $0.81 \mathrm{~mm}$, 0.92 and $1.13 \mathrm{~mm}$, and 1.19 and $1.40 \mathrm{~mm}$, respectively. The overlap of growth increments increased with fish age and the increments of older ages were not well individualised (Fig. 3b).

In vertebrae, the deposition of growth increments from the centrum to the outer margin was characterised by two different patterns: in the innermost region, growth increments were wide (typically the first 6 bands) and afterwards they were much thin-

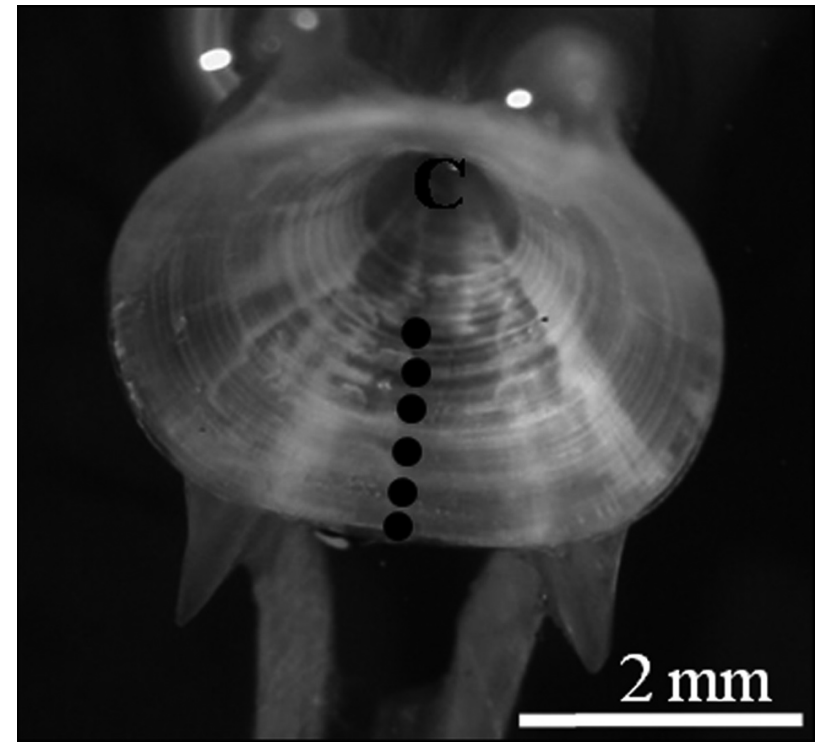

FIG. 4. - Vertebra from a specimen of Aphanopus carbo caught off mainland Portugal, with $1036 \mathrm{~mm}$ total length and 6 years. Black dots represent growth increments. C, centrum.

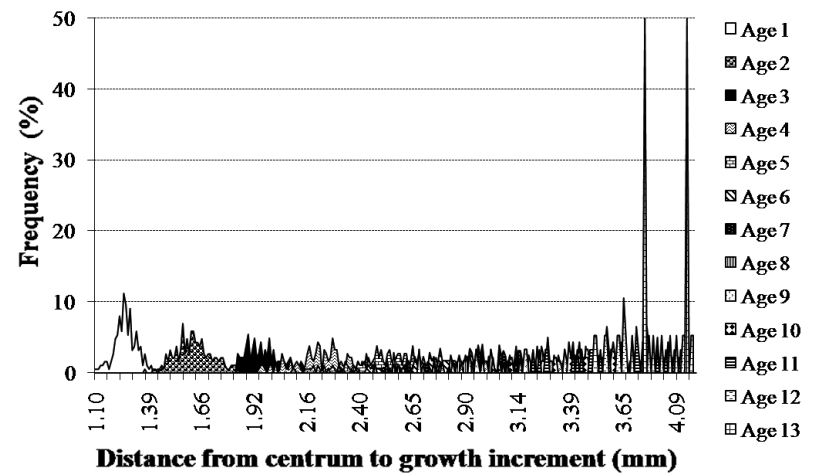

FIG. 5. - Individualisation of growth increments by age from Aphanopus carbo vertebrae caught off mainland Portugal.

ner, and each of them was assumed to be a growth increment (Fig. 4). Comparing vertebrae with both whole and sectioned otoliths, the growth increments 


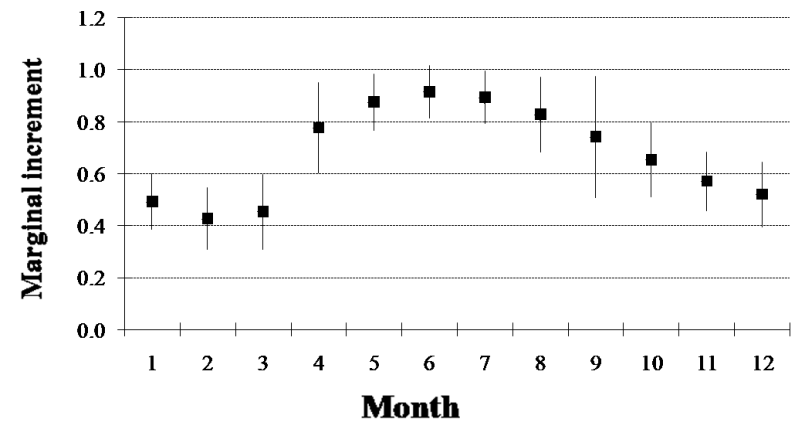

FIG. 6. - Monthly evolution of marginal increment analysis (MIA) in sectioned otoliths of Aphanopus carbo from mainland Portugal.

in vertebrae were overlapped greatly with each other (Fig. 5), so the band deposition involved greater difficulty.

\section{Age determination and growth comparisons}

The marginal increment analysis (MIA) showed that there is a clear annual pattern of growth incre- ment formation, with the marginal increment showing an increasing trend from March to June, and maintaining the higher values between April and September (Fig. 6). The low values of MIA found between November and February indicates that the new band is formed during this period.

Comparing the age assigned using whole or sectioned otoliths between readers, ages of between 4 to 13 years were allocated. Through the vertebrae observation, reader 1 assigned ages between 4 and 14 years, and reader 2 ages between 4 and 15 years. Table 3 presents the indexes of precision between ageing preparation methods. Reader 1 showed a good precision between whole and sectioned otoliths, with a high level of agreement (Fig. 7a). For this reader, age assignment between vertebrae and sectioned otoliths resulted in a lower precision and a poorer level of agreement (Fig. 7b). Reader 2 showed low values of precision indexes and a good agreement for the comparisons between whole and sectioned otoliths

TABLE 3. - Measures of precision for age readings on Aphanopus carbo between ageing preparation methods.

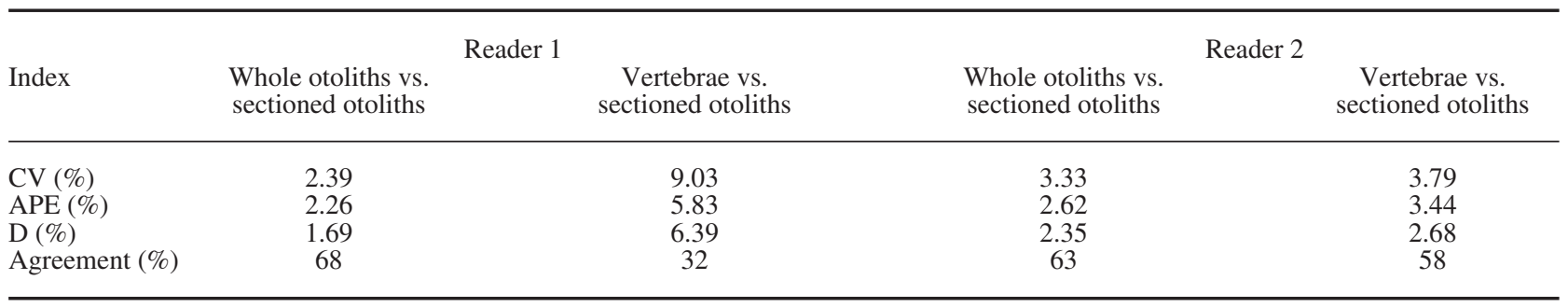

Reader 1

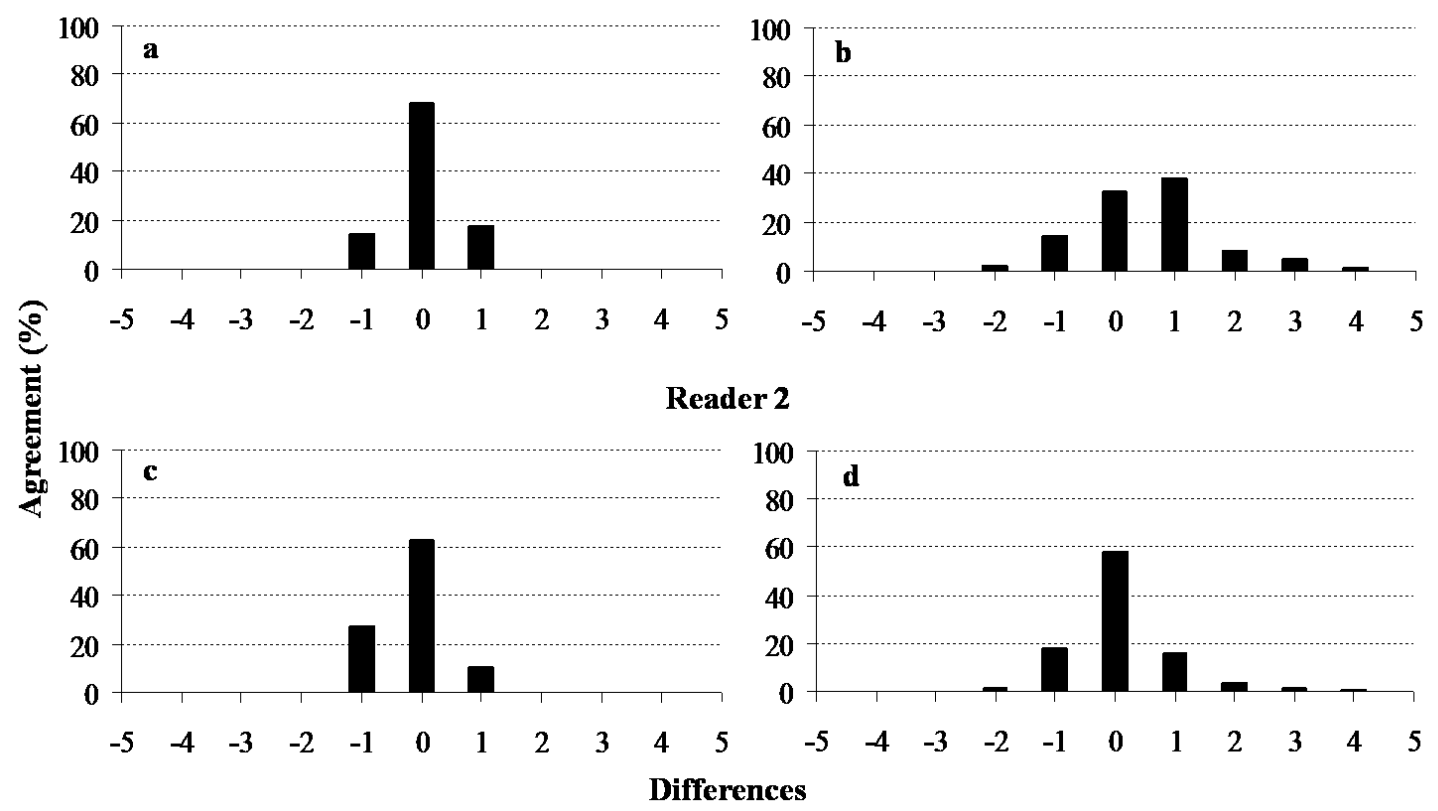

FIG. 7. - Bias plot comparing ageing preparation methods for each reader based on Aphanopus carbo; (a) and (c) between whole and sectioned otoliths; (b) and (d) between vertebrae and sectioned otoliths. 
TABle 4. - Measure of precision for age readings on Aphanopus carbo between reader 1 and reader 2 .

\begin{tabular}{lccc}
\hline Index & Whole otoliths & Sectioned otoliths & Vertebrae \\
\hline CV (\%) & 4.57 & 1.70 & 12.20 \\
APE (\%) & 3.29 & 1.13 & 6.90 \\
D (\%) & 3.23 & 1.20 & 8.63 \\
Agreement (\%) & 55 & 83 & 37 \\
\hline
\end{tabular}

and between vertebrae and sectioned otoliths. However, this last comparison presented a lower level of agreement than the first one (Fig. 7c and d).

For reader 1, the paired t-test applied to compare age assigned by different methods revealed significant differences between vertebrae and sectioned otoliths $(\mathrm{p}=0.033)$ and non-significant mean paired differences between whole and sectioned otoliths $(\mathrm{p}=0.914)$. For reader 2, both comparisons
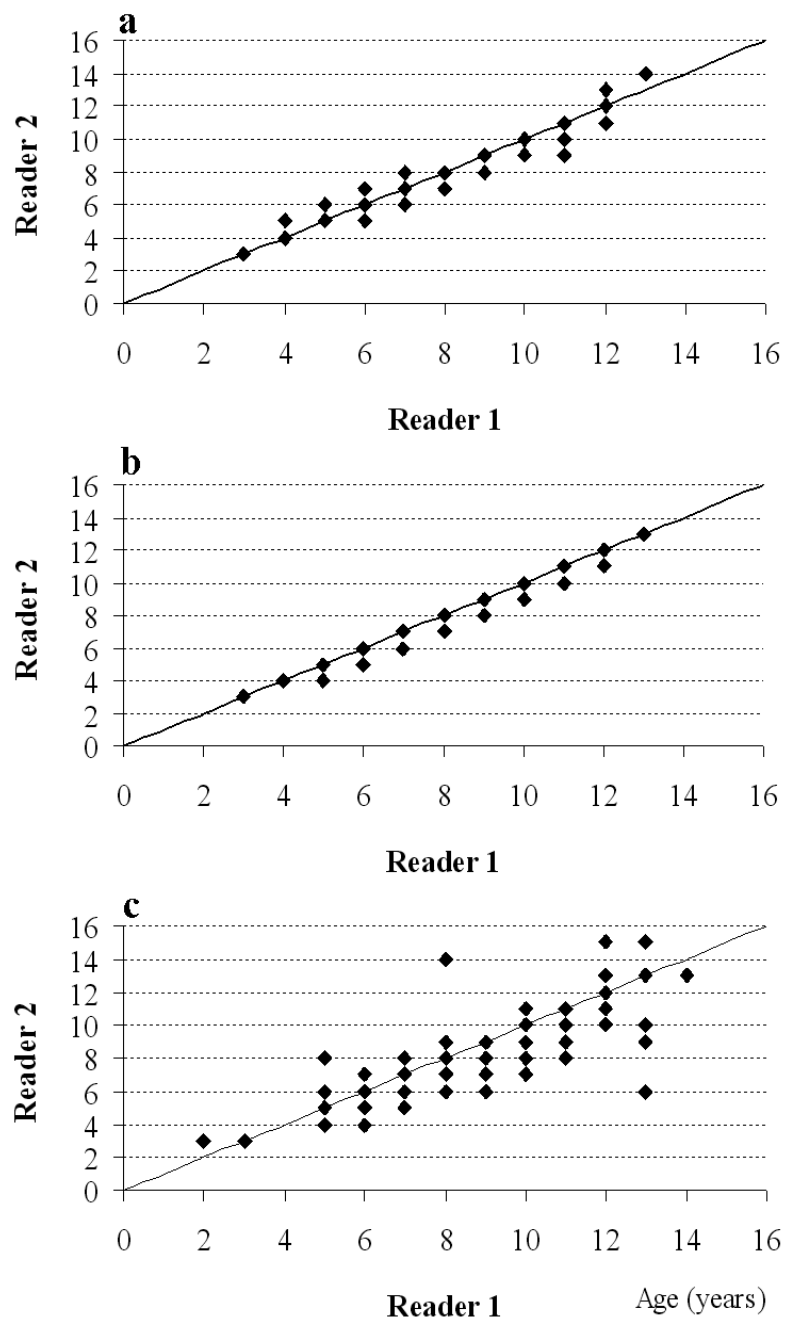

FIG. 8. - Agreement plot for comparisons between ages assigned by reader 1 and reader 2 for Aphanopus carbo specimens from mainland Portugal. (a) Whole otoliths. (b) Sectioned otoliths. (c) Vertebrae. The $45^{\circ}$ line represents $100 \%$ agreement. (whole and sectioned otoliths, and vertebrae and sectioned otoliths) revealed non-significant differences ( $\mathrm{p}=0.480$ and $\mathrm{p}=0.552$, respectively).

The results obtained between whole and sectioned otoliths from the extra sample of Madeira specimens showed a good agreement $(\mathrm{CV}=2.06 \%$; $\mathrm{APE}=2.38 \% ; \mathrm{D}=1.16 \%$; \% agreement $=50$ ), and no significant differences between readings were revealed $(\mathrm{p}=0.145)$.

Table 4 shows the indexes of precision between readers. A high level of agreement and lower $\mathrm{CV}$, APE and D indicated an elevated precision between both sectioned and whole otoliths, although the highest precision was obtained for sectioned otoliths. For vertebrae a lower agreement was determined. Analysing the agreement plot comparing age assignment between readers (Fig. 8), the lowest variation was observed in the sectioned otoliths (Fig. 8b), although reader 2 tended to assign slightly lower ages than reader 1 , especially in ages greater than 8 . The parametric paired t-test showed non-significant differences in comparisons between whole and sectioned otoliths ( $\mathrm{p}=0.175$ and $\mathrm{p}=0.477$, respectively), and significant differences in comparisons between vertebrae. There was no evidence of systematic disagreement between reader 1 and reader 2 for ages assigned by sectioned otoliths and vertebrae (test of symmetry, $\chi^{2}=25.00$, d.f. $=20, p=0.201$ and $\chi^{2}=58.27$, d.f. $=48, p=0.147$, respectively). For ages assigned by whole otoliths, there was evidence of systematic disagreement between reader 1 and reader 2 (test of symmetry, $\chi^{2}=80.31$, d.f. $=27, p=0.000$ ).

Age-length keys were calculated by sex and year for Madeira and mainland Portugal and by sex in Azores specimens, due to the lower number of individuals obtained. The comparison of the different time series in mainland Portugal and Madeira resulted in no significant differences (Table 5) between years, and the data were hence pooled for each region. The differences in length distributions obtained in the different regions consequently resulted in a great variability in the age distributions.

TABLE 5. - Results of the comparison of the age-length keys of different time series in mainland Portugal and Madeira.

\begin{tabular}{lcccc}
\hline Area & Sex & D.f. & F & p value \\
\hline Mainland Portugal & females & 12 & 1.60698 & 0.090226 \\
madeira & 13 & 1.52994 & 0.112488 \\
& $\begin{array}{c}\text { females } \\
\text { males }\end{array}$ & 4 & 2.41794 & 0.050494 \\
& & 0.69762 & 0.594515 \\
\hline
\end{tabular}



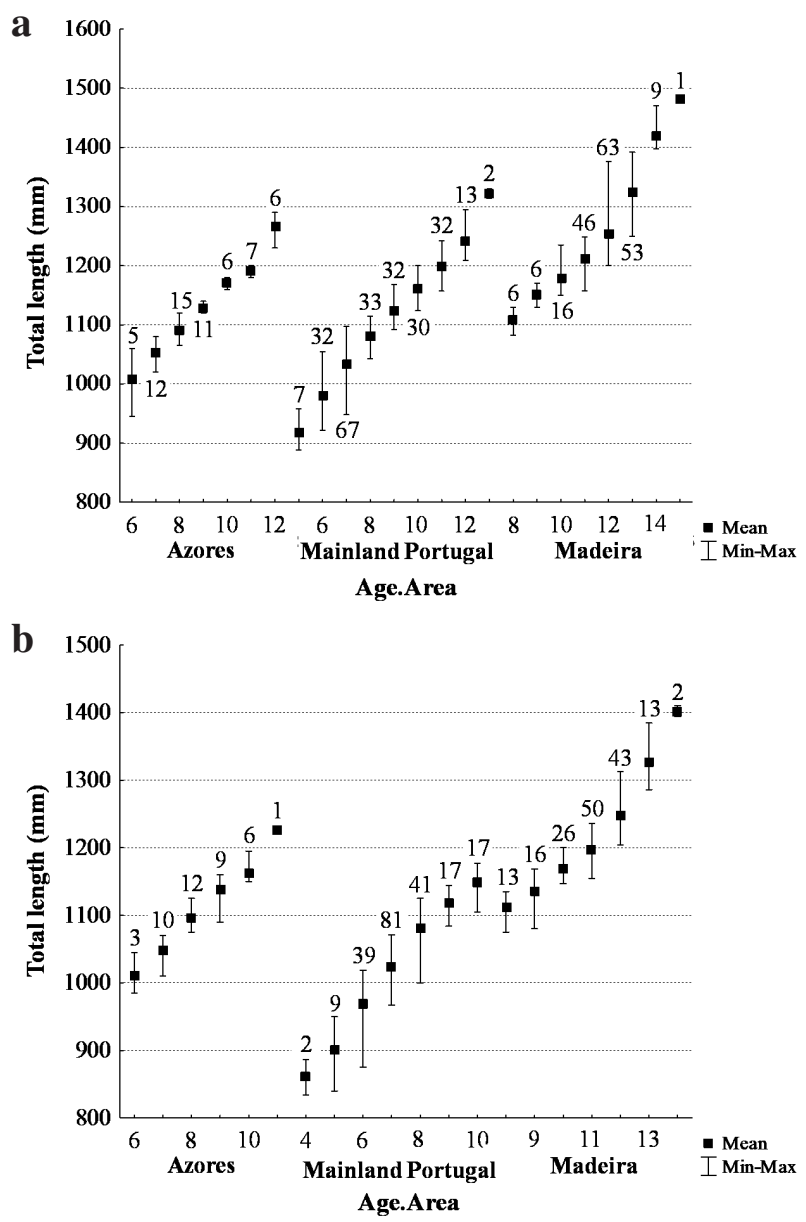

FIG. 9. - Distributions of length-at-age for Aphanopus carbo caught off Azores, mainland Portugal and Madeira; (a) females; (b) males. Numbers plotted with symbols are the sample size at age.

Ages ranged between 4 and 12 (13) respectively for males and females from mainland Portugal; between 8 and 14 (15) respectively for males and females from Madeira, and from 6 to 12 for both males and females from the Azores (Fig. 9).

There were significant differences in the comparison of the age-length keys between males and females from mainland Portugal and Madeira $(\mathrm{p}<0.001)$ but no significant differences were found between sexes in the Azores specimens $(p=0.134)$. Therefore, the subsequent analyses were made separately by sex for
TABLE 6. - Relationships between the total length (TL) and the otolith radius (OR) in the females and males of Aphanopus carbo from mainland Portugal and Madeira.

\begin{tabular}{lcll}
\hline Area & Sex & TL:OR relationship & \\
\hline Mainland & females & TL $=705.5$ OR $^{0.540}$ & $\mathrm{r}=0.810$ \\
& males & TL $=688.8 \mathrm{OR}^{0.557}$ & $\mathrm{r}=0.859$ \\
Madeira & females & $\mathrm{TL}=642.0 \mathrm{OR}^{0.869}$ & $\mathrm{r}=0.848$ \\
& males & $\mathrm{TL}=590.5 \mathrm{OR}^{0.973}$ & $\mathrm{r}=0.901$ \\
\hline
\end{tabular}

the first two study areas. Due to the uneven amount of otoliths read in the three regions, two analyses were made: a first one to compare the distributions of length-at-age between Madeira and mainland Portugal, and a second one including the Azores.

In the comparison of the distributions of lengthat-age between females from mainland Portugal and Madeira and also between males from mainland Portugal and Madeira, significant differences were found $(\mathrm{p}<0.001)$ : the Madeira specimens attained greater lengths for the same age (Fig. 9). Significant differences were also found when the Azorean data were included in the analysis $(\mathrm{p}<0.001)$ : the Madeira specimens showed the greatest lengths-at-age and the individuals from mainland Portugal the lowest ones (Fig. 9). The high increments observed in the oldest age classes (e.g. in females, age 12 in the Azores samples, age 13 in mainland samples and ages 14 and 15 in the Madeira samples, Fig. 9a) are due to the lower number of individuals sampled in these classes associated with the greater difficulty in ageing these individuals.

The relationships between total length and otolith radius are presented in Table 6 and the results of the von Bertalanffy growth model are summarised in Table 7. Madeira specimens attained a greater length and had a lower growth rate than those from mainland Portugal and females attained a greater length than males in both regions. Statistical differences were obtained in the comparison of the growth parameters for females $\left(\mathrm{T}^{2}=18.84 ; \mathrm{T}_{0}^{2}=11.97 ; \mathrm{T}^{2}>\mathrm{T}_{0}{ }^{2}\right)$ and for males $\left(\mathrm{T}^{2}=44.38 ; \mathrm{T}_{0}^{2}=10.41 ; \mathrm{T}^{2}>\mathrm{T}_{0}^{2}\right)$ between Madeira and mainland Portugal.

TABLE 7. - Summary of von Bertalanffy growth model for Aphanopus carbo caught off mainland Portugal and Madeira. Standard deviation in parenthesis.

\begin{tabular}{lccccc}
\hline Area & Sex & $\mathrm{L}_{\infty}(\mathrm{mm})$ & $\mathrm{k}\left(\mathrm{year}^{-1}\right)$ & $\mathrm{T}_{0}($ year $)$ & $\mathrm{r}$ \\
\hline Mainland & females & $1354(42.68)$ & $0.170(0.022)$ & $-2.040(0.378)$ & 0.952 \\
Madeira & males & $1240(28.99)$ & $0.208(0.021)$ & $-1.654(0.284)$ & 0.941 \\
& females & $1586(41.37)$ & $0.119(0.009)$ & $-2.282(0.224)$ & 0.971 \\
& males & $1461(12.78)$ & $0.146(0.004)$ & $-1.441(0.065)$ & 0.965 \\
\hline
\end{tabular}




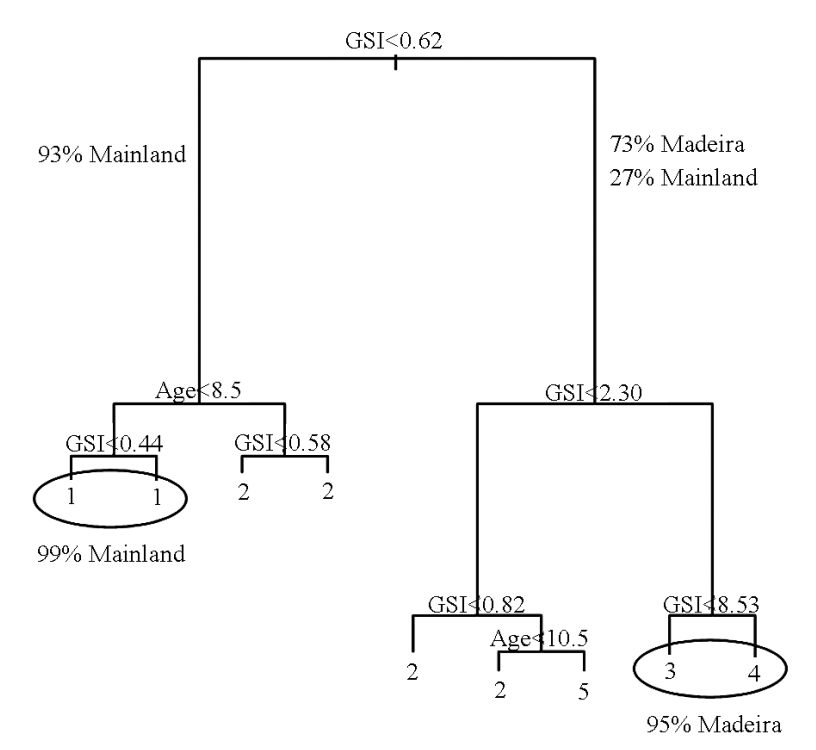

FIG. 10. - Application of the regression tree to female Aphanopus carbo data (GSI, age and maturity). The numbers (1 to 5) at the end of the tree branches refer to the maturity stages. The oval shapes group the individuals from the same area (with percentage of correct classification indicated).

\section{Reproduction effect upon growth}

The regression tree model for females (Fig. 10) showed that the first split was associated with GSI: one group with a GSI lower than 0.62 , which corresponds almost exclusively (93\%) to specimens from mainland Portugal and the other group incorporated females with a GSI higher than 0.62, and included mainly females from Madeira (73\%).

The first group was further divided according to age. The individuals with an age lower than 8 , which were mainly immature females, were separated from developing females, which typically had an age of more than 8 years. This latter group was further split into two groups according to their GSI, the lower values corresponding to females from mainland Portugal and the higher values to females from both mainland Portugal and Madeira (in a lower proportion).

The second group of fish (with a GSI higher than 0.62) was further split into two groups according to the GSI value of 2.30. The first group, of females with a GSI lower than 2.30, included developing females from mainland Portugal (those with an age lower than 10) and developing females from Madeira (with an age higher than 10 years). In the second group, which included almost exclusively (95\%) females from Madeira, pre-spawning were separated from spawning females (GSI>8.53).

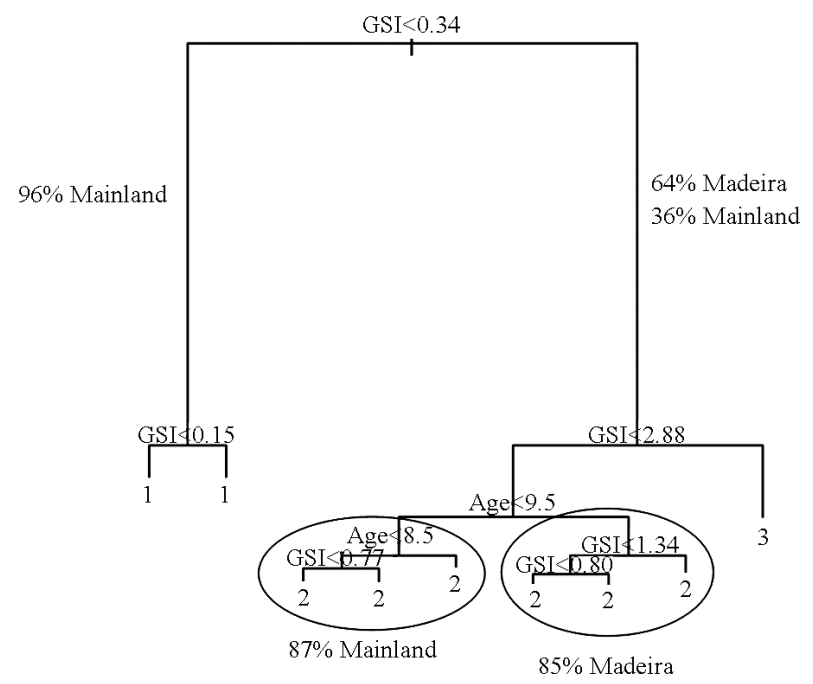

Fig. 11. - Application of the regression tree to male Aphanopus carbo data (GSI, age and maturity). The numbers (1 to 5) at the end of the tree branches refer to the maturity stages. The oval shapes group the individuals from the same area (with percentage of correct classification indicated).

The male regression tree (Fig. 11) showed a pattern similar to the females' regression tree, the first split discriminating the individuals from mainland Portugal. Furthermore, as for females, the first split was associated with GSI: one group with a GSI lower than 0.34, which included almost exclusively (96\%) specimens from mainland Portugal and one group of males with a GSI higher than 0.34 that included individuals from Madeira (64\%) and mainland Portugal $(36 \%)$. In this second group, males from Madeira mainly had a GSI higher than 2.88; if they had a lower GSI they were older than 9 years. On the other hand, males from mainland Portugal had a GSI lower than 2.88 and an age lower than 9 years.

\section{DISCUSSION}

\section{Ageing methodology}

Repeated age determinations of a sample of fish are generally conducted in order to determine whether there are systematic differences in age estimates between one or more age readers or methodologies, or to estimate the precision of the age estimate (Campana et al., 1995). Of the two, it is the precision estimate that is most often reported, probably because the analysis implicitly assumes that no systematic differences existed. The presence of systematic differences (bias) in interpreting age structures poses the most serious problem for those responsible for 
conducting age determinations, because it will confound the interpretation of most measures of precision (Campana et al., 1995). One of the aims of this paper was to test and improve the precision of age readings by determining the best reading structure for black scabbardfish and evaluating the interpretation criteria. Previous studies on this species age used different otolith methodologies and gave age ranges of between 8 years (Morales-Nin and SenaCarvalho, 1996) and 12 years (Morales-Nin et al., 2002; Pajuelo et al., 2008) using whole otoliths, and up to 32 years (Kelly et al., 1998) using sectioned otoliths. Morales-Nin et al. (2002) assumed that these discrepancies should be due to the preparation of otoliths and interpretation of increment patterns, since the fish length range was similar in all studies. Though whole otoliths have been commonly adopted in age assignment of black scabbardfish, the results obtained in this study showed that this technique is suitable for ageing specimens up to 1100 $\mathrm{mm}$ but creates several ageing problems for larger specimens, when the discrimination of growth increments becomes more difficult. On the other hand, the sectioned otoliths proved to be the best method for ageing larger specimens because growth increments can be seen without difficulty. Augustine and Kenchington (1987) also found that in some species otoliths from specimens below a certain size can be viewed intact, whereas sectioning is required for larges fishes. Dwyer et al. (2003), studying Limanda ferruginea, also suggest that growth increments subsequent to the first 5-7 years are more difficult to see in whole otoliths.

In fact, in shorter specimens ( $\mathrm{TL}<1100 \mathrm{~mm}$ ) no differences were found in the number of growth increments observed between whole and sectioned otoliths, and between all reading areas for the same otolith. However, in otoliths of larger specimens the posterior region of whole otoliths and the dorsal face of sectioned ones allowed a better individualisation of the first growth increments. Morales-Nin et al. (2002) report that the preparation of sectioned otoliths is not advantageous because it causes added difficulty in locating the true increments, because the false rings became more evident. This was not verified in this study, because there was a good level of agreement, for both readers, between whole and sectioned otolith readings, resulting in good precision indexes. The ranges of the precision estimates calculated for both readers were well below the average values reported in the literature (Campana, 2001). The comparisons between readers (by t-test and test of symmetry) showed much better precision and agreement between sectioned otoliths than between whole otoliths. Furthermore, no statistically significant differences were found in comparisons between otolith methodologies in each reader and between readers, no evidence was found of systematic disagreement between readers, and sectioned otoliths allowed better ageing for larger specimens. For all of these reasons, this technique appears to be the most appropriate method for age assignment in this species.

Black scabbardfish growth increments proved to be more difficult to interpret in vertebrae than in otoliths. The main difficulties found were the imprecision of the first growth increment and the probable presence of faint bands between true rings. Other authors have also experienced some difficulties in vertebra ageing. Pérez and Fabré (2003) in Calophysus macropterus identified the presence of intermediate growth marks, which occur between the main growth marks (those that are counted for determining the age). Panfili (1993) and VillacortaCorrea (1997) failed to observe a pattern of deposition in the vertebrae of Colossoma macropomum due to the high frequency of intermediate growth marks. Campana (2001) reports that the value of the coefficient of variation for vertebra readings in species with moderate longevity and reading complexity ranged between $6 \%$ and $12 \%$, corresponding to an average of $9.5 \%$. Therefore, although the results for ageing black scabbardfish vertebrae are within or even lower than those limits, it should be said that vertebrae are not the most appropriate structure for age assignment of this species. However, in the absence of otoliths (as in the case of French longline landings), vertebrae may be useful in age assignment of black scabbardfish specimens.

As a conclusion on the evaluation of the best structure for ageing, based on the observations made in this study, which complemented a previously study on black scabbardfish otolith preparation methods (Morales-Nin et al., 2002), the readability of black scabbardfish otoliths was improved by the thin-sectioning method, and this method should therefore be implemented as the standard methodology in ageing this species.

\section{Age determination and growth comparisons}

Age and growth are among the life history parameters used to analyse the stock structure of a species. 
However, as life history parameters may vary temporally within stocks, the use of a single time frame to interpret any life history parameter will be very misleading and emphasises the need to investigate the temporal variation in these parameters (Begg et al., 1999). To overcome this situation, a longer time frame was used in both regions of Portugal where a commercially fishery exists. The presence of no significant differences in the age distribution between the years may be seen as the presence of some stability of both environmental conditions and fishing pressure. Further, the black scabbardfish population is composed of several age classes, giving some resilience to short-term variability. Moreover, the immature juvenile fish are seldom caught by the fishery, which means that this important fraction of the population does not suffer a high fishing mortality.

The uneven distribution of length-at-age associated with poorer information on age data from the Azores made it impossible to apply a growth model to the three regions and compare parameters. We therefore followed the alternative approach proposed by Begg (2005) and pursued by Abaunza et al. (2008) of statistically comparing the mean lengths-at-age among the regions in evaluation across a common age range. The results corroborate the presence of distinct stock management units. Quinta et al. (2004), based on the frequency of the restriction patterns of mtDNA, suggest that the black scabbardfish stock in the northeastern Atlantic is genetically structured, being divided into two groups: one from the eastern Atlantic (mainland Portugal and Hatton Bank) and one from around the Madeira archipelago. This study corroborates the present one. However, Stefanni and Knutsen (2007), in a study based on phylogeography and demographic history of black scabbardfish using mtDNA, suggest that Madeira, mainland Portugal and the Faraday Seamount are included in the same phylogroup, and found no evidence of the stock structure reported by Quinta et al. (2004). Another paper, based on the microchemical analysis of whole otoliths (Swan et al., 2003) showed that there were only small differences between the overall chemical signature of the otoliths from all studied areas (Reykjanes Ridge, Hatton Bank, Rockall Trough, mid-Atlantic Ridge, mainland Portugal and Madeira Archipelago), and this is consistent with the single stock hypothesis. There are very few works on the growth of black scabbardfish. Morales-Nin and Sena-Carvalho (1996) considered that the species off Madeira attained a maximum age of 8 years and a fast growth rate $\left(\mathrm{k}=0.25\right.$ year $\left.^{-1}\right)$. Two years later, Kelly et al. (1998) reported a maximum age of 32 years based on sectioned otoliths of specimens caught in Irish waters. In 2002, after a workshop on the age and growth of this species (Morales-Nin et al., 2002), it was considered that the maximum age reported by Morales-Nin and Sena-Carvalho (1996) could be underestimated and that the species could reach older ages (at least 12 years). Using sectioned instead of whole otoliths, the distribution of lengthat-age assigned in the present work gives a maximum age of 15 years and a lower growth rate in Madeiran specimens $\left(\mathrm{k}=0.12\right.$ and 0.15 year $^{-1}$, respectively for females and males). Recently, in the Canary Islands Pajuelo et al. (2008) reported a maximum age of 12 years but a higher growth rate $\left(k=0.20\right.$ year $\left.^{-1}\right)$, which is more evident in the first years of life, with 2- and 3 -year old females attaining $1120 \mathrm{~mm}$ and $1220 \mathrm{~mm}$ TL respectively. The results obtained by the different authors (and besides the discrepancies shown in the distribution of length-at-age that can be overcome with an interchange otolith programme) show the black scabbardfish to be a relatively fast-growing species. The assignment of such high growth rates to deep-water species, as observed for black scabbardfish, is frequently questionable, since it is commonly accepted that deep-water species are k-strategists and hence tend to exhibit slow growth and attain a high longevity. Nonetheless, that is not true for some deepwater species, such as the abyssal macrourid Coryphaenoides armatus and the giganturoid Bathysaurus ferox (Sulak et al., 1985), for which rapid growth is observed until it reaches the full adult size. This strategy has been seen as an advantage both in feeding success and predatory avoidance (Merrett and Haedrich, 1997).

\section{Reproduction effect upon growth}

Sex seems to have a fundamental influence on the growth rates of the individuals living in the waters of both Madeira and mainland Portugal, the females (and particularly those from Madeiran waters) having a lower growth rate. This reduction in the growth rate seems to be related to the reproductive effort. In fact, in all species the obtained energy is firstly committed to survival, including body maintenance costs, with the surplus energy being allocated to growth and reproduction. The differential growth pattern between the females from mainland Portugal (non-reproductive females, Neves et al., 2009) and Madeira (reproductive females, Neves et al., 2009) 
may reflect the optimisation of the energetic balances. This optimisation strategy is perfectly suited to the food-constrained environment in which this species lives (Gartner et al., 1997). Growth and reproduction of individuals are two physiological processes based on the partitioning of net production (i.e. energy acquisition rate minus maintenance rate) between growth and energy reserves (reproduction uses energy reserves) (Houston and McNamara, 1999). It is generally accepted that feeding of organisms modulates their allocation of net production in response to their total energy contents (energy in the reserves plus energy bounded to structural biomass) and also that the adopted allocation strategy keeps its total energy constant (Lika and Nisbet, 2000). In the case of both males and non-reproductive females from mainland Portugal, the absence of such an energy switch between growth and reproduction is due to a lower energy demand for gonad development; therefore, they can canalise most of their energy to growth. Observations on slope-dwelling fishes in the Rockall Trough and Porcupine Seabight (Gordon et $a l ., 1995)$ suggest that in many deep-water species females become mature only after reaching adult size and when somatic growth has slowed down or ceased (Haedrich, 1997). These and our results suggest that energy is available for either growth or reproduction but not for both. Also, as the reproduction success is tied to the body size (Roff, 1992), the attaining of a large size before maturity $(c a .103 \mathrm{~cm}$, Figueiredo et al., 2003) can be energetically advantageous for black scabbardfish.

In conclusion, we can state that the black scabbardfish shows differences in the age and growth of the specimens living off mainland Portugal, Madeira and the Azores (and most probably Canary Islands). These differences might arise due to the differential population fraction analysed, or the different habitat characteristics of each study area. A relevant finding is the stability in the population parameters over an 8 -year period, showing that, although determined by sex and sexual stage, black scabbardfish demography has not changed. This finding might be related to a fairly stable fishing pressure (Bordalo-Machado and Figueiredo, 2009) in a long-developed fishery.

\section{ACKNOWLEDGEMENTS}

We would like to thank Joana Vasconcelos and Sara Reis (Madeira archipelago) and Valentina Cos- ta (Azores archipelago) for providing the otoliths. This study was partially supported by the Fundação para a Ciência e Tecnologia (project POCTI/ CVT/46851/2002).

\section{REFERENCES}

Abaunza, P., L.S. Gordo, M.T. García Santamaría, S.A. Iversen, A.G. Murta and E. Gallo. - 2008. Life history parameters as basis for the initial recognition of stock management units in horse mackerel (Trachurus trachurus). Fish. Res., 89: 167-180.

Anon. - 2000. Final report of the EU study project CT 97/0084 Environment and biology of deep-water species Aphanopus carbo in NE Atlantic: basis for its management (BASBLACK). DGXIV European commission.

Augustine, O. and T.J. Kenchington. - 1987. A low-cost saw for sectioning otoliths. J. Cons. Int. Explor. Mer, 43: 296-298.

Beamish, R.J. and D.A. Fournier. - 1981. A method for comparing the precision of a set of age determinations. Can. J. Fish. Aquat. Sci., 38: 982-983.

Beckman, D.W. and C.A. Wilson. - 1995. Seasonal timing of opaque zone formation in fish otoliths. In: D.H. Secor, J.M. Dean and S.E. Campana (eds.), Recent Developments in Fish Otoliths Research, pp. 27-43. University of South Carolina Press, Columbia.

Bedford. B.C. - 1983. A method for preparing sections of large numbers of otoliths embedded in black polyester resin. J. Cons. Int. Explor. Mer, 41: 4-12.

Begg, G.A. - 2005. Life history parameters. In: S.X. Cadrin, K.D. Friedland and J.R. Waldman (eds.), Stock identification methods: applications in fisheries science, pp. 119-150. Elsevier Academic Press, MA, USA.

Begg, G.A., J.A. Hare and D.D. Sheehan. - 1999. The role of life history parameters as indicators of stock structure. Fish. Res., 43: 141-163.

Bergstad, O.A. - 1995. Age determination of deep-water fishes: experiences, status and challenges for the future. In: A.G. Hopper (eds.), Deep-water Fisheries of the North Atlantic Oceanic Slope, pp. 267-283. Kluwer Academic Publishers, Dordrecht.

Bernard, D.R. - 1981. Multivariate analysis as a means of comparing growth in fish. Can. J. Fish. Aquat. Sci., 38: 233-236.

Bordalo-Machado, P. and I. Figueiredo. - 2009. The fishery for black scabbardfish (Aphanopus carbo Lowe, 1839) in the Portuguese continental slope. Rev. Fish Biol. Fish., 19: 49-67.

Bowker, A.H. - 1948. A test for symmetry in contingency tables. $J$. Am. Stat. Assoc., 43: 572-574.

Campana, S.E. - 1999. Chemistry and composition of fish otoliths: pathways, mechanisms and applications. Mar. Ecol. Prog. Ser., 188: 263-297.

Campana, S.E. - 2001. Accuracy, precision and quality control in age determination including a review of the use and abuse of age validation methods. J. Fish. Biol., 59: 197-242.

Campana, S.E., M.C. Annand and J.I. McMillan. - 1995. Graphical and statistical methods for determining the consistency of age determinations. Trans. Am. Fish. Soc., 124: 131-138.

Carvalho, D. - 1988. Relatório final do estudo efectuado sobre o Peixe-Espada Preto (Aphanopus carbo, Lowe, 1839) capturado na ZEE da Madeira. EC Report. DG XIV/CE Doc. No. XIV/B/1-1987.

Chang, W.Y.B. - 1982. A statistical method for evaluating the reproducibility of age determination. Can. J. Fish. Aquat. Sci., 39: 1208-1210.

Dwyer, K.S., S.J. Walsh and S.E. Campana. - 2003. Age determination, validation and growth of Grand Bank yellowtail flounder (Limanda ferruginea). ICES J. Mar. Sci., 60: 1123-1138.

Erzini, K. - 1994. An empirical study of variability in length-at-age of marine fishes. J. Appl. Ichthyol., 10: 17-41.

Figueiredo, I., P. Bordalo-Machado, S. Reis, D. Sena-Carvalho, T. Blasdale, A. Newton, and L.S. Gordo. - 2003. Observations on the reproductive cycle of the black scabbardfish (Aphanopus carbo Lowe, 1839) in the NE Atlantic. ICES J. Mar. Sci., 60: 774-779. 
Gartner, J.V. Jr, R.E. Crabtree and K.J. Sulak. - 1997. Feeding at depth. In: D.J. Randall and A.P. Farrell (eds.), Deep-sea fishes, pp. 115-193. Academic Press, New York.

Gayanilo, F.C.Jr., P. Sparre and D. Pauly. - 2005. The FAOICLARM stock-assessment tools II (FiSAT II). Revised version. User's guide. FAO Computerized Information Series (Fisheries) 8, FAO, Rome, 168 pp.

Gordo, L.S., D.S. Carvalho, I. Figueiredo, S. Reis, P.B. Machado, A. Newton, and J. Gordon. - 2000. Escala de maturação sexual do peixe-espada preto: uma abordagem macro e microscópica. The sexual maturity scale of black scabbardfish: a macro-and microscopic approach. Celta Editora, Oeiras.

Gordon, J.D.M., N.R. Merrett and R.L. Haedrich. - 1995. Environmental and biological aspects of slope dwelling fishes. In: A.G. Hopper (ed.), Deep-water fisheries of the North Atlantic Oceanic slope, pp. 1-30. Kluwer Academic Publishers, Dordrecht, The Netherlands.

Haedrich, R.L. - 1997. Distribution and population ecology. In: D.J. Randall and A.P. Farrell (eds.), Deep-sea fishes, pp. 79-114. Academic Press, New York.

Hilborn, R. and C.J. Walters. - 1992. Quantitative Fisheries Stock Assessment: Choice, Dinamycs, and Uncertain. Chapman \& Hall, New York.

Hoenig, J.M., M.J. Morgan and C.A. Brown. - 1995. Analysing differences between two age determination methods by tests of symmetry. Can. J. Fish. Aquat. Sci., 52: 364-368.

Houston, A.I. and J.M. McNamara. - 1999. Models of adaptive behaviour: an approach based on state. Cambridge University Press, Cambridge, U.K.

Kelly, C.J., P.L. Connolly and M.W. Clarke. - 1998. The deep water fisheries of the Rockall trough: some insights gleaned from Irish survey data. ICES CM 1998/O:40, 22 pp.

Large, P.A., C. Hammer, O.A. Bergstad, J.D.M. Gordon and P. Lorance. - 2003. Deep-water fisheries of the Northeast Atlantic: II Assessment and management approaches. J. Northw. Atl. Fish. Sci., 31: 151-163.

Lika, K. and R.M. Nisbet. - 2000. A dynamic energy budget model based on partitioning of net production. J. Math. Biol., 41: 361-386.

Martins, M.R., A.M. Leite and M.L. Nunes. - 1987. Peixe-espadapreto. Algumas notas acerca da pescaria do peixe-espada-preto. Instituto Nacional de Investigação das Pescas (publicações avulsas), Lisboa.

McCurdy, W.J. - 1985. A low-speed alternative method for cutting otolith sections. J. Cons. Int. Explor. Mer, 42: 186-187.

Merrett, N.R. and R.L. Haedrich. - 1997. Deep-sea demersal fish and fisheries. Chapman and Hall, London.

Morales-Nin, B. and D. Sena-Carvalho. - 1996. Age and growth of black scabbard fish (Aphanopus carbo) off Madeira. Fish. Res., 25: 239-251.

Morales-Nin, B. and J. Panfili. - 2005. Seasonality in the deep-sea and tropics revisited: what can otoliths tell us? J. Mar. Freshw. Res., 56: 585-598.

Morales-Nin, B., Â. Canha, M. Casas, I. Figueiredo, L.S. Gordo, M. Gordon, E. Gouveia, C.G. Piñeiro, S. Reis, A. Reis and S.C.
Swan. - 2002. Intercalibration of age readings of deepwater black scabbardfish, Aphanopus carbo (Lowe, 1839). ICES J. Mar. Sci., 59: 352-364.

Nakamura, I. and N.V. Parin. - 1993. FAO Species Catalogue. Snake mackerels and cutlassfishes of the world (Families Gempylidae and Trichiuridae). An annotated and illustrated catalogue of snake mackerels, snoeks, escolars, gemfishes, sackfishes, domine, oilfish, cutlassfishes, scabbardfishes, hairtails, and frostfishes known to date. FAO Fisheries Synopsis, 125(15): 1-136.

Neves, A., A.R. Vieira, I. Farias, I. Figueiredo, V. Sequeira and L.S. Gordo. - 2009. Reproductive strategies in black scabbardfish (Aphanopus carbo Lowe, 1839) from NE Atlantic. Sci. Mar., 73S2: 19-31.

Pajuelo, J.G, J.A. González, J.I. Santana, J.M. Lorenzo, A. GarcíaMederos and V. Tuset. - 2008. Biological parameters on the bathyal fish black scabbardfish (Aphanopus carbo Lowe, 1839) off the Canary Islands, Central-east Atlantic. Fish. Res., 92: 140-147.

Panfili, J. - 1993. Estimation d'âge individuel des poissons: méthodologies et applications á des populations naturelles tropicales et tempérées. Diplôme de Doctorat. Université de Montpellier, France.

Pérez, A. and N. Fabré. - 2003. Seleção das estruturas calcificadas para a determinação da idade da piracatinga Calophysus macropterus Lichtenstein (Siluriformes: Pimelodidae) na Amazónia Central, Brasil. Acta Amazon., 33(3): 499-514.

Quinta, R., L. Gomes and A.T. Santos. - 2004. A mitochondrial DNA PCR-RFLP marker for population studies of the black scabbardfish (Aphanopus carbo). ICES J. Mar. Sci., 61: 864-867.

Roff, D.A. - 1992. The evolution of life histories, theory and analysis. Chapman and Hall, New York.

Stefanni, S. and H. Knutsen. - 2007. Phylogeography and demography history of the deep-sea fish Aphanopus carbo (Lowe, 1839) in the NE Atlantic: Vicariance followed secondary contact of speciation? Mol. Phylogenet. Evol., 42: 38-46.

Sulak, K.J., C.A. Wenner, G.R. Sedberry and L. van Guelpen. 1985. The life history and systematics of deep-sea lizard fishes, genus Bathysaurus (Synodontidae). Can. J. Zool., 63: 623-642.

Swan, S.C., J.M.D. Gordon and T. Shimmield. - 2003. Preliminary investigations in the use of otolith microchemistry for stock discrimination of deep-water black scabbardfish (Aphanopus carbo) in the North East Atlantic. J. Northw. Atl. Fish. Sci., 31: 221-231.

Villacorta-Corrêa, M. - 1997. Crescimento do matrinxã, Brycon cephalus (Gunther, 1969) (teleostei: Characidae) no baixo rio negro, seus afluentes e no baixo Solimões. Dissertação de Mestrado. Instituto Nacional de Pesquisas da Amazónia, Fundação Universidade do Amazonas. Manaus, Amazonas.

von Bertalanffy, L. - 1938. A quantitative theory of organic growth (inquiries of growth laws II). Hum. Biol., 10: 181-213.

Scient. ed.: J. Lleonart.

Received December 16, 2008. Accepted October 9, 2009.

Published online December 22, 2009. 